\title{
Working Capital Management: A Study on British American Tobacco Bangladesh Company Ltd.
}

\author{
Md. Sayaduzzaman
}

\begin{abstract}
The efficiency of working capital management of British American Tobacco Bangladesh Company Ltd. is highly satisfactory due to the positive cash in flows, planned approach in managing the major elements of working capital. Applications of multi-dimensional models of current assets mix may have positive impact on the continuous growth \& development of this multinational enterprise. This depends on co-operation of the stakeholders and business environment in the context of globalization.
\end{abstract}

Key words: working capital, work-in-progress

BANGLADESH TOBACCO COMPANY LTD. (BTC) was a sister concern of British American Tobacco Company Ltd. (BATC). The history of BTC goes back to 1926 when Messrs Usher Smith and Hadridas Roy opened a branch office of Imperial Tobacco Company Ltd. It was formed with the assets and liabilities of Indian Tobacco Company (ITC) Ltd. held in Pakistan. The War of Liberation was fought in 1971 and a new country, Bangladesh was born. On the second day of February 1972, Bangladesh Tobacco Company Limited was incorporated under the Company Act of 1913 with the assets and liabilities of Pakistan Tobacco Company Limited. The share of BATCO was 67 percent, while 32 percent share was given to the Bangladeshi shareholders. The paid up capital was Tk. 3.75 crores.

Very recently the Company has been renamed as British American Tobacco Bangladesh Company Ltd. (BATBCL). It has a cigarette factory at Mohakhali in Dhaka and a leaf factory at Kushtia. It has leaf depots and sales depots all over the country. It has 33,000 registered tobacco farmers; they are given all possible supports by the company to grow quality tobacco. The company markets 13 brands of cigarettes and pipe tobacco throughout Bangladesh. The company has provided direct job opportunities of about 3,200 people and contributes a large amount of money each year to the national exchequer in the form of custom duty, income tax, VAT and excise duty. Working capital management is a new area emphasized for the productive utilization of their available funds created out of good cash flows, financial solvency and growth strategies. This study may enlighten the different ways and techniques of working capital management to develop the sound financial base of the company.

\section{Objectives of the Study}

The major objective of the present study is to examine and evaluate the working capital management in BATBCL over a period of 5 years (1999-2000 to 2002-2003). The specific objectives of the study are as under:

(a) To examine the management pattern of inventory in the BATBCL during 1999-2003.

(b) To analyze and evaluate receivables management along with its impact on working capital management.

(c) To analyze cash position and the efficiency with which the same is managed during 
the period.

(d) To assess the current liability positions and the efficiency with which the overall working capital is managed.

(e) To suggest some measures for improvement in working capital management of BATBCL.

\section{Hypotheses}

The following hypotheses are tested in the present study:

$\mathrm{H} 1$ : There is a positive correlation between efficiency in working capital and profitability of the BATBCL.

$\mathrm{H} 2$ : There is a positive correlation between market ratio and profitability of the company.

$\mathrm{H} 3$ : There is also correlation between efficiency ratio and profitability ratio.

$\mathrm{H} 4$ : There is also positive correlation between efficiency ratio and market ratio.

H5: There is positive correlation between liquidity and market ratio.

\section{Review of Past Studies}

Extensive research works on working capital management have been done in both public and private sectors including Multinational Companies in Bangladesh. Mohiuddin (1983) had conducted a study on cash budget. The cardinal objectives of budgeting are planning, coordinating, and controlling, all these three are there in cash budget. Therefore, the effectiveness of cash budget minimizes liquidity problems.

Islam and Rahman (1994) had article on " Working capital Trends of the Selected Enterprises in Bangladesh". Optimum working capital enables a business to have its credit standing and permits the debts payments on the date of its maturity and helps to keep itself fairly in liquid position which enables the business to attract borrowing from the banks. It also helps to maintain all-round efficiency in operations. Of all aspects of financial management, working capital management is the vital one.

\section{Conceptual Design of the Study}

Working capital in simple terms is the amount of funds which a company needs to finance its day by day operations. Opinions differ on the concept of working capital. Gross working capital is defined as the firms' total currents asset. The purpose of the present study is to analyze the various concepts of working capital and find out the feasibility of the concept of working capital in the light of better planning and control of working capital. A concept of gross working capital adheres to the overall investment in current assets and financing of the same. Networking capital refers to the excess of current assets over current liabilities (1990).

Problems of working capital management involve the problem of determining the optimum level of investment in each component of current assets i.e. inventory, receivables cash, and other short term investment. The basic focus in managing working capital should be to optimize the firm's investment in them. An expert in the financial management is of the opinion that problem of working capital is one of the factors responsible for the low profitability in manufacturing sector. Better planning and control of working capital or in other words, proper utilization of optimum quantity of working capital increases the earning power subject to the existence of operating margin (1980). 


\section{Methodology of the Study}

The sample of the study is BATBCL which is the largest Tobacco Company in Bangladesh. The study covers five years period from 1999-2000 to 2002-2003. This study is based on both secondary and primary data. Secondary data are the annual reports of the company and various studies made available through library work. The primary data was collected from the field survey. The researcher visited BATBCL Head Office as also its branch offices to collect information through personal interviews with their executives. A particular interview schedule was used for the purpose of interview.

The collected data have been tabulated, analyzed and interpreted with the help of different financial ratios and statistical tools like percentages, average, trend analysis, correlation and significance test, etc. Five hypotheses have been tested statistically to arrive at conclusion and policy implications.

\section{Major Findings}

6.1 Working capital management of the BATBCL Is highly satisfactory due to efficient management of inventory, debtors, cash balances and working funds.

6.2 Monthly requirements for working capital are about 10 crores of Taka, these are collected both from internal and external sources.

6.3 Cash credit facilities are given by National Commercial Banks (NCBs) at a lower rate of interest.

6.4 The forecast of working capital is done through estimating monthly productions, needs for raw materials, and other direct expenses.

6.5 The major elements of working capital are inventory, debtors, cash balances and short term investments.

6.6 Inventories are grouped into raw materials, work in process, finished goods, stores and spares etc.

6.7 Inventory management of the company is highly effective. Modern techniques of inventory management like Economic Order Quantity (EOQ), ABC analysis, maximum and minimum level of inventory, CPM / PERT etc. are followed in a routine way.

6.8 The major sources of raw materials are local sources and USA, UK, etc.

6.9 Purchase procedure is done through separate department for purchase. There is no purchase problem at all.

6.10 Control of Work-in- Progress (WIP) is hampered due to power failure and mechanical troubles.

6.11 Finished goods like cigarettes have good demand in market. There is no question of stockpiling at all.

6.12 Credit sales are given to the dealers and high commissions are allowed. No difficulty is found in collection of receivables. For early payment of dues, cash discount facility is given, sometimes accounts receivables are grouped in to ageing schedule.

6.13 Cash management of the company is done through cash budget, cash flow statement and other steps.

6.14 Due to good operating profits, there is little difficulty in cash management. The liquidity position of the company is highly satisfactory. External debts are also very limited.

6.15 The company easily achieves the breakeven point every year due to satisfactory sales, 
controlled cost and maximum capacity utilization.

6.16 Every year performance evaluation is done highlighting the different ratios.

6.17 Budgetary control of the company is highly effective through the use of operating and financial budgets. The productivity of the company is highly satisfactory due to good man management relation.

6.18 The company has bright prospects due to efficient management of mace, machine materials \& technology.

6.19 The company follows wide human resource management through staff development program.

6.20 Total quality management, participating management decisions and management audit and ethical audit are regulatory followed.

6.21 The company has good sources of internal finance. This reduces the borrowings and financial leverage, this favors ROI and good equity base.

6.22 Market research activities show heavy demand for their products it create good market for selling quality products at a higher price, yielding good sources of working capital.

6.23 The company has successful uses of working capital due to planned inventory, receivables, cash, finance and good cash inflow.

\section{Hypothesis Testing}

There is a positive correlation between efficiency in working capital and profitability of the BATBCL.

Table 1: Correlation Matrix

\begin{tabular}{|c|c|c|c|c|c|c|c|c|}
\hline & $\begin{array}{l}\text { Quick } \\
\text { Ratio }\end{array}$ & $\begin{array}{c}\text { Current } \\
\text { Ratio }\end{array}$ & $\begin{array}{c}\text { Gross } \\
\text { Profit } \\
\text { Margin } \\
\end{array}$ & $\begin{array}{c}\text { Net } \\
\text { Operating } \\
\text { Margin } \\
\end{array}$ & $\begin{array}{c}\text { Profit } \\
\text { Margin } \\
\text { on Scales }\end{array}$ & $\begin{array}{c}\text { Return } \\
\text { on Total } \\
\text { Assets }\end{array}$ & $\begin{array}{c}\text { Return } \\
\text { on } \\
\text { Equity } \\
\end{array}$ & 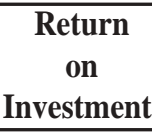 \\
\hline Return on total assets & 1 & 0.234 & 0.132 & 0.234 & 0.362 & -0.022 & 0.189 & 0.094 \\
\hline Current Ratio & & 1 & -0.528 & -0.031 & 0.473 & 0.301 & 0.192 & 0.325 \\
\hline Gross profit margin & & & 1 & 0.425 & -0.255 & -0.347 & -0.204 & -0.407 \\
\hline Net operating margin & & & & 1 & 0.74 & 0.688 & 0.787 & 0.649 \\
\hline Profit margin on sales & & & & & 1 & $0.913 *$ & $0.944 *$ & $0.937 *$ \\
\hline Return on total assets & & & & & & 1 & $0.964 * *$ & * $0.988 * *$ \\
\hline Return on equity & & & & & & & & $10.974 * *$ \\
\hline Return on investment & & & & & & & & 1 \\
\hline
\end{tabular}

* Correlation is significant at the 0.05 level (2-tailed). ** Correlation is significant at the 0.01 level (2-tailed).

Table 1 shows the relationship between the efficiency of working capital and profitability of BATBCL. The efficiency of working capital has been shown through the quick and current ratios of the company. It has been found that the quick ratio of the company was negatively related with the return on total assets, but positively related with other profitability variables considered in this analysis. On the other hand, the current ratio of the company was negatively related with gross profit margin and net operating margin, but positively related with rest of the profitability variables. Though there are relationship existing within the efficiency of working capital and the profitability, but these relationships are not statistically significant.

2. There is a positive correlation between market ratio and profitability of the company. 
Table 2: Correlation Matrix on Earnings

\begin{tabular}{|c|c|c|c|c|c|c|c|c|c|c|c|c|}
\hline & $\begin{array}{c}\text { Gross } \\
\text { Profit } \\
\text { Margin }\end{array}$ & $\begin{array}{c}\text { Net } \\
\text { Opera- } \\
\text { ting } \\
\text { Margin }\end{array}$ & $\begin{array}{c}\text { Profit } \\
\text { Margin } \\
\text { on } \\
\text { Sales }\end{array}$ & $\begin{array}{c}\text { Return } \\
\text { on } \\
\text { Total } \\
\text { Assets }\end{array}$ & $\begin{array}{l}\text { Return } \\
\text { on } \\
\text { Equity }\end{array}$ & $\begin{array}{l}\text { Return } \\
\text { on } \\
\text { Invest- } \\
\text { ment }\end{array}$ & $\begin{array}{l}\text { Earning } \\
\text { per } \\
\text { Share }\end{array}$ & $\begin{array}{l}\text { ig Price } \\
\text { Earning } \\
\text { e \& } \\
\text { Ratio }\end{array}$ & $\begin{array}{l}\text { Divi- } \\
\text { dend } \\
\text { Yield }\end{array}$ & $\begin{array}{c}\text { Market } \\
\text { to } \\
\text { Book } \\
\text { Ratio }\end{array}$ & $\begin{array}{c}\text { Pay } \\
\text { out } \\
\text { Ratio }\end{array}$ & $\begin{array}{c}\text { Divi- } \\
\text { dend } \\
\text { per } \\
\text { Share }\end{array}$ \\
\hline Sross profit margin & 1 & 0.425 & -0.255 & -0.347 & -0.204 & -0.407 & 0.153 & -0.614 & 0.712 & -0.817 & -0.509 & $9-0.155$ \\
\hline Net o & & 1 & 0.74 & 0.688 & 0.787 & 0.649 & 0.872 & -0.731 & $0.91 *$ & -0.172 & -0.166 & 60.715 \\
\hline Profit mar & & & 1 & $0.91^{*}$ & $0.94 *$ & $0.94 *$ & 0.723 & -0.27 & 0.399 & 0.46 & 0.16 & 60.755 \\
\hline Retur & & & & 1 & $0.96^{* *}$ & $0.99 * *$ & 0.811 & -0.293 & 0.405 & 0.425 & 0.264 & $40.92 *$ \\
\hline Returr & & & & & 1 & $0.97 * *$ & $0.89 *$ & -0.475 & 0.519 & 0.265 & 0.022 & 20.832 \\
\hline Returr & & & & & & 1 & 0.791 & -0.28 & 0.338 & 0.453 & 0.199 & $\begin{array}{ll}9 & 0.85\end{array}$ \\
\hline Earn & & & & & & & & -0.795 & 0.781 & -0.18 & -0.261 & 10.769 \\
\hline Dric & & & & & & & & 1 & -0.858 & 0.721 & 0.724 & $4-0.286$ \\
\hline & & & & & & & & & & -0.531 & -0.344 & 40.533 \\
\hline & & & & & & & & & & 1 & 0.791 & 10.317 \\
\hline & & & & & & & & & & & & 10.414 \\
\hline Dividend per share & & & & & & & & & & & & \\
\hline
\end{tabular}

* Correlation is significant at the 0.05 level (2-tailed). ** Correlation is significant at the 0.01 level (2-tailed).

Table 2 shows the relationship between the market ratio and profitability of the BATC. It has been found that the gross profit is positively correlated with net profit, earning per share and dividend yield of the company, but negatively correlated with all of the other variables. Net profit margin is only significantly correlated with dividend yield. Profit margin on sales is significantly correlates with return on total assets, return on equity and return on investment. Return on total assets is significantly correlated with return on equity, return on investment and dividend per share. And return on equity is significantly correlated with return on investment and earning per share.

3. There is also correlation between efficiency ratio and profitability ratio.

Table 3: Correlation Matrix on Earnings and Activity Level

\begin{tabular}{|c|c|c|c|c|c|c|c|c|c|c|}
\hline & $\begin{array}{c}\text { Gross } \\
\text { Profit } \\
\text { Margin }\end{array}$ & $\begin{array}{c}\text { Net } \\
\text { Opera- } \\
\text { n ting } \\
\text { Margin }\end{array}$ & $\begin{array}{c}\text { Profit } \\
\text { Margin } \\
\text { on } \\
\text { Sales } \\
\end{array}$ & $\begin{array}{c}\text { Return } \\
\text { on } \\
\text { Total } \\
\text { Assets } \\
\end{array}$ & $\begin{array}{c}\text { Return } \\
\text { on } \\
\text { Equity }\end{array}$ & $\begin{array}{c}\text { Return } \\
\text { on } \\
\text { Invest- } \\
\text { ment } \\
\end{array}$ & $\begin{array}{c}\text { Sales } \\
\text { to } \\
\text { Fixed } \\
\text { Assets } \\
\end{array}$ & $\begin{array}{c}\text { Sales } \\
\text { to } \\
\text { Total } \\
\text { Assets } \\
\end{array}$ & $\begin{array}{c}\text { Inven- } \\
\text { tory } \\
\text { Turnover } \\
\text { Ratio } \\
\end{array}$ & $\begin{array}{c}\text { Average } \\
\text { Collection } \\
\text { Period }\end{array}$ \\
\hline Gross profit margin & 1 & 0.425 & -0.255 & -0.347 & -0.204 & -0.407 & -0.818 & -0.71 & -0.198 & 0.355 \\
\hline Net operating margin & & 1 & 0.74 & 0.688 & 0.787 & 0.649 & 0.153 & 0.205 & -0.061 & -0.096 \\
\hline Profit margin on sales & & & 1 & $0.913 *$ & $0.944 *$ & $0.937 *$ & 0.745 & 0.603 & 0.309 & -0.134 \\
\hline Return on total assets & & & & 1 & $0.964 * *$ & $0.988 * *$ & 0.784 & 0.833 & -0.07 & -0.525 \\
\hline Return on equity & & & & & 1 & $0.974 * *$ & 0.673 & 0.709 & 0.014 & -0.351 \\
\hline investment & & & & & & 1 & 0.817 & 0.829 & 0.033 & -0.442 \\
\hline Sales to fixed assets & & & & & & & 1 & 0.851 & 0.261 & -0.391 \\
\hline Sales to total assets & & & & & & & & 1 & $1-0.263$ & -0.775 \\
\hline Inventory turnover ratio & & & & & & & & & 1 & 0.78 \\
\hline Average collection period & & & & & & & & & & 1 \\
\hline
\end{tabular}

*Correlation is significant at the 0.05 level (2-tailed). **Correlation is significant at the 0.01 level (2-tailed).

Table 3 shows the relationship between the efficiency ratio and profitability ratio of BATBCL. Average collection period is negatively correlated with all the profitability ratios except with the gross profit margin and these relationships are not statistically significant. Inventory turnover ratio is positively correlated with return on equity and return on investment but negatively correlated with other profitability variables and these relationships are 
also not statistically significant. Sales to total assets are positively correlated with all profitability variables except with the gross profit margin. These relationships are not statistically significant.

4. There is also positive correlation between efficiency ratio and market ratio.

Table 4: Correlation Matrix on Growth ratios and Earnings

\begin{tabular}{|c|c|c|c|c|c|c|c|c|c|c|}
\hline & $\begin{array}{c}\text { Sales } \\
\text { to } \\
\text { Fixed } \\
\text { Assets }\end{array}$ & $\begin{array}{c}\text { Sales } \\
\text { to } \\
\text { Total } \\
\text { Assets }\end{array}$ & $\begin{array}{c}\text { Inventory } \\
\text { Turnover } \\
\text { Ratio }\end{array}$ & $\begin{array}{l}\text { Aver- } \\
\text { age } \\
\text { Colle- } \\
\text { ction }\end{array}$ & $\begin{array}{c}\text { Earning } \\
\text { per } \\
\text { Share }\end{array}$ & $\begin{array}{c}\text { S Price } \\
\text { Earning } \\
\text { Ratio }\end{array}$ & $\begin{array}{l}\text { Divi- } \\
\text { dend } \\
\text { Yield }\end{array}$ & $\begin{array}{c}\text { Marke } \\
\text { to Bool } \\
\text { Ratio }\end{array}$ & $\begin{array}{c}\text { Pay } \\
\text { out } \\
\text { Ratio }\end{array}$ & $\begin{array}{c}\begin{array}{c}\text { Divi- } \\
\text { dend } \\
\text { per }\end{array} \\
\text { Share }\end{array}$ \\
\hline Sales to fixed assets & 1 & 0.851 & 0.261 & -0.391 & 0.3 & 0.312 & -0.234 & 0.863 & 0.56 & 0.614 \\
\hline Sales to total assets & & 1 & -0.263 & -0.775 & 0.528 & 0.024 & -0.042 & 0.55 & 0.404 & 0.746 \\
\hline Inventory turnover ratio & & & 1 & 0.78 & -0.314 & 0.37 & -0.323 & 0.471 & 0.047 & -0.309 \\
\hline Average collection period & & & & 1 & -0.408 & 0.059 & -0.101 & -0.153 & -0.403 & -0.67 \\
\hline Earnings per share & & & & & 1 & -0.795 & 0.781 & -0.18 & -0.261 & 0.769 \\
\hline Price earning ratio & & & & & & 1 & -0.858 & 0.721 & 0.724 & -0.286 \\
\hline Dividend yield & & & & & & & 1 & -0.531 & -0.344 & 0.533 \\
\hline Market to book ratio & & & & & & & & 1 & 0.791 & 0.317 \\
\hline Pay out ratio & & & & & & & & & 1 & 0.414 \\
\hline Dividend per share & & & & & & & & & & 1 \\
\hline
\end{tabular}

Table 4 shows the relationship between the efficiency ratio and market ratio of BATBCL. From the above analysis it has been found that there is no significant correlation among the variables. Dividend yield ratio is negatively correlated with all the efficiency ratios except with the earnings per share. Market to book ratio is negatively correlated with average collection period, price earning ratio and dividend yield but positively correlated with all the efficiency ratios. Pay out ratio is also negatively correlated with average collection period, price earning ratio and dividend yield but positively correlated with all the efficiency ratios. Dividend per share is negatively correlated with inventory turnover, average collection period and price earning ratio but positively correlated with all other efficiency ratios of the company.

5. Positive correlation is found between liquidity and market ratio.

Table 5: Correlation Matrix on Liquidity Ratios

\begin{tabular}{|c|c|c|c|c|c|c|c|c|}
\hline & $\begin{array}{l}\text { Quick } \\
\text { Ratio }\end{array}$ & $\begin{array}{c}\text { Current } \\
\text { Ratio }\end{array}$ & $\begin{array}{c}\text { Earnings } \\
\text { per } \\
\text { Share }\end{array}$ & $\begin{array}{c}\text { Price } \\
\text { Earning } \\
\text { Ratio }\end{array}$ & $\begin{array}{l}\text { Divedend } \\
\text { Yield }\end{array}$ & $\begin{array}{c}\text { Market } \\
\text { to Book } \\
\text { Ratio }\end{array}$ & $\begin{array}{c}\text { Pay-out } \\
\text { Ratio }\end{array}$ & $\begin{array}{c}\text { Dividend } \\
\text { per } \\
\text { Share }\end{array}$ \\
\hline Quick Ratio & 1 & 0.234 & 0.055 & -0.189 & 0.067 & 0.00 & -0.486 & -0.309 \\
\hline Current Ratio & & 1 & -0.241 & 0.673 & -0.373 & $0.91 *$ & 0.733 & 0.222 \\
\hline Earnings per share & & & 1 & -0.795 & 0.781 & -0.18 & -0.261 & 0.769 \\
\hline Price earning ratio & & & & 1 & -0.858 & 0.721 & 0.724 & -0.286 \\
\hline Dividend yield & & & & & 1 & -0.531 & -0.344 & 0.533 \\
\hline Market to book ratio & & & & & & 1 & 0.791 & 0.317 \\
\hline Pay out ratio & & & & & & & 1 & 0.414 \\
\hline Dividend per share & & & & & & & & 1 \\
\hline
\end{tabular}

* Correlation is significant at the 0.05 level (2-tailed).

Table 5 shows the relationship between the liquidity and market ratio of the BATBCL. There are statistically significant relationship only between the current ratio and market to book ratio, and all other relationships are not statistically significant. Quick ratio has no relationship with the market to book ratio. On the other hand, current ratio is positively correlated with earnings per share and dividend yield, but negatively correlated with price 
earning ratio, pay out ratio and dividend per share. Current ratio is negatively correlated with earnings per share and dividend yield, but positively correlated with all other market ratios.

\section{Conclusion and Recommendations}

Working capital management of BATBC Ltd. is highly effective. The project is very much profitable. There is available internal source of fund due to satisfactory amount of period during the period under study. Mill has no problem in management of inventory, debtors, cash balances and current liabilities. The liquidity position of the company is also very much satisfactory due to good turnover of current assets, inventory debtors and cash balances. The company enjoys good facility of cash credit and other working capital loan from different commercial banks. There is no difficulty in repayment of current liabilities out of the operating profit. In addition to operating profit, there is ample non-operating profit on security investment, dividend and other revenues.

Planning and Control of cash balances follow cash-flow statement. It shows the sources and uses of cash over the period. Regular funds flow statements are also prepared by the company. This helps in designing working capital planning, control, monitoring, utilization and productive maintenance of optimum size of working capital. Financial statement shows the current assets and current liabilities in classified form. There is good collection of receivables due to good credit and collection policy. Credit sales are made frequently but no stockpiling and stuck up debtors are found. Due to good utilization of working capital, the business growth of the company is also highly satisfactory. Market prices of shares are increasing year after year due to good dividend and good image in the market. The company has a good share within the direct foreign investment. Government. has given more facilities for the direct foreign investors. This has increased the managerial efficiency of the tobacco company. However, in view of the concluding remarks, the following suggestions are given for increasing efficiency in working capital management.

(a) Particular norms for working capital management should be followed to reduce the market risk.

(b) Liquidity management activities may be more organized through using idle funds for productive investments.

(c) Inter firm comparison should be made from time to time with similar organization.

(d) Horizontal analysis and vertical analysis through ratio techniques would be more meaningful.

(e) Financial information system should be introduced to develop financial discipline in working capital management.

(f) Working Capital Norms for maintaining optimum quantity of raw materials, Work - in - Progress, Finished goods \& store and spares are to be developed.

(g) Financial forecasting, planning and control devices are to be more intensive to enhance the efficacy of cash management.

\section{REFERENCES}

Islam, M.R. and Rahman, M. M.1994. Working capital Trends the Selected Enterprises in Bangladesh. Rajshahi University Studies, Part-C, Vol. 2, 1994.

Kennedy, M. 1980. Financial Management. New Delhi: McGraw Hill Book Co.

Ministry of Finance, Bangladesh. 1990. Economic Review. Govt. of the People's Republic of Bangladesh.

Mohiuddin, M. Feb. 1983. Cash Budget - An Effective Means To Solve Liquidity Problem. The Cost and Management.

Panday, I.M. 1990. Financial Management. New Delhi: Vikash Publications House. 